\title{
(6) OPEN ACCESS \\ Understanding the emergence of the tobacco industry's use of the term tobacco harm reduction in order to inform public health policy
}

\author{
Silvy Peeters, Anna B Gilmore
}

Department for Health, University of Bath, Bath, UK

\section{Correspondence to}

Silvy Peeters, Department for Health, University of Bath,

Claverton Down, Bath,

BA2 7AY, UK;

s.peeters@bath.ac.uk

Accepted 13 December 2013

Published Online First

23 January 2014

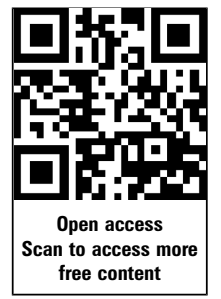

CrossMark

To cite: Peeters $S$

Gilmore AB. Tob Control

2015:24:182-189.
ABSTRACT

Objectives To explore the history of transnational tobacco companies' use of the term, approach to and perceived benefits of 'harm reduction'.

Methods Analysis of internal tobacco industry documents, contemporary tobacco industry literature and 6 semistructured interviews.

Results The 2001 Institute of Medicine report on tobacco harm reduction appears to have been pivotal in shaping industry discourse. Documents suggest British American Tobacco and Philip Morris International adopted the term 'harm reduction' from Institute of Medicine, then proceeded to heavily emphasise the term in their corporate messaging. Documents and interviews suggest harm reduction offered the tobacco industry two main benefits: an opportunity to (re-) establish dialogue with and access to policy makers, scientists and public health groups and to secure reputational benefits via an emerging corporate social responsibility agenda.

Conclusions Transnational tobacco companies' harm reduction discourse should be seen as opportunistic tactical adaptation to policy change rather than a genuine commitment to harm reduction. Care should be taken that this does not undermine gains hitherto secured in efforts to reduce the ability of the tobacco industry to inappropriately influence policy.

\section{INTRODUCTION}

In a 2005 speech at the National Press Club in Australia, David Davies, then Philip Morris International's (PMI) Senior Vice-president Corporate Affairs, suggested PMI shared significant common ground with the public health community, and that his company could be 'a positive contributor, indeed a partner in shaping future policy for tobacco' (authors' emphasis). ${ }^{1}$ Davies was referring to the concept of 'tobacco harm reduction', a term that has increasingly entered the tobacco industry's vernacular. For example, in 2008 British American Tobacco (BAT) set up a special website (http://www. bat-science.com) promoting their research and development (R\&D) efforts in developing potentially reduced harm tobacco products. David O'Reilly, BAT's Scientific Director, states on this website that he believes that 'tobacco harm reduction has the potential to be one of the biggest public health opportunities of this generation' (accessed March 2013). ${ }^{2}$ Similarly, other BAT employees have begun publicly commenting on academic papers addressing harm reduction issues, offering 'to work with the public health community and regulators to achieve a reduction in the public health impact of tobacco use'. ${ }^{4}$
The public health community has been divided over the possible benefits of tobacco harm reduction, with the debate in Europe focused hitherto on a low risk smokeless tobacco (SLT) product, snus, ${ }^{5}$ and more recently on e-cigarettes. ${ }^{6}$ Public health interest in snus began following observations of the so-called 'Swedish Experience', which attributes Sweden's low male smoking prevalence, and resulting low levels of tobacco-related mortality, to high rates of snus use among Swedish men. ${ }^{7-9}$ With overwhelming evidence that snus is considerably less harmful than smoking, and that nicotine addiction is the key reason why smokers continue to smoke, this raises the potential for lives to be saved if smokers could switch from cigarettes to using nicotine in a less hazardous form such as snus. ${ }^{10}$

While an Australian modelling study suggests that the introduction of snus should reduce harm at a population level, ${ }^{11}$ others argue that the extent to which this may occur will depend on how snus is marketed, who takes it up, and whether it successfully enables smokers to quit cigarettes. ${ }^{12}{ }^{13}$ Concerns focus mainly on the possibility that marketing of snus may lead to an increase in dual tobacco use rather than a decrease in cigarette smoking or to snus acting as a gateway into tobacco use for non-smokers.

In the European Union (EU), with the exception of Sweden, the sale of snus has been prohibited since $1992 .{ }^{14}$ Despite this ban, the four transnational tobacco companies (TTCs) operating on the European tobacco market (BAT, PMI, Imperial Tobacco (IMT) and Japan Tobacco International (JTI)) have been acquiring, or entering into joint ventures with, Swedish snus manufacturers, to the extent that small independent manufacturers only account for an insignificant proportion of the Scandinavian snus market (the only snus market in Europe).${ }^{15}{ }^{16}$ Concurrently, TTCs have started publicly opposing this ban on snus sales, supporting their position with a harm reduction narrative. ${ }^{17-19}$ Yet recent research shows this narrative is inconsistent with the TTCs' private documentation which suggests that harm reduction is not central to their business strategy. ${ }^{16}$ In addition, evidence from the USA, an established SLT market, suggests that snus is being marketed to augment cigarette use. ${ }^{20-23}$

This paper seeks to examine TTCs' use of the term 'harm reduction'. It examines when and why harm reduction first entered TTC's discourse, and explores the TTCs' approach to and perceived benefits of harm reduction. In so doing it aims to assess whether the tobacco industry's interest in harm reduction reflects opportunistic tactical 
adaptation to policy change, or a substantive commitment to harm reduction.

\section{METHODS}

Our study was based on internal tobacco company documents, available on the online Legacy Tobacco Documents Library (http://legacy.library.ucsf.edu/) following litigation in the USA. ${ }^{24}$ The Legacy Library was searched between May 2010 and February 2013, with searches focused on the two largest TTCs, PMI and BAT. PMI has been through various restructures, with its current form established in 2008 when it spun off from Altria (known pre-2003 as Philip Morris Companies). ${ }^{15}$ For simplicity purposes, we refer to 'PMI' throughout this paper. Documents were initially retrieved using broad search terms (eg, 'harm reduction', 'smokeless tobacco', 'R\&D strategy'). The documents retrieved helped identify secondary search terms including relevant internal committees (eg, BAT's Tobacco Executive Committee and BAT's Research Policy Group) and key personnel. Surrounding Bates numbers of key documents were also searched. The iterative process of searching, analysing and refining resulted in a final set of 455 documents, dating from 1971 to 2009 . Analysis of these documents was based on a hermeneutical approach to company document analysis, ${ }^{25}$ complemented by sociohistorical archival techniques. ${ }^{26}$

To validate and update this documentary evidence, and specifically to explore when and how tobacco industry discourse on harm reduction was introduced and changed, we triangulated the documentary evidence obtained with data from other tobacco industry sources. First, we searched the TTCs' corporate websites (http://www.bat.com, http://www.pmi.com, http://www. jti.com, http://www.imperial-tobacco.com) to identify their position on harm reduction. Second we searched TTCs' annual reports for the terms 'harm reduction', 'reduced harm', 'smokeless' and 'snus', recording all occurrences. This analysis was undertaken on all reports accessible online, via the British Library and personal contacts in October 2012: 1997-2011 annual reports for BAT (minus the 1998 report); 1997-2011 annual reports for IMT; 2005-2012 annual reports for JTI; and 2002-2011 annual reports for PMI.

As our document and website searches identified BAT as particularly vocal on harm reduction we further explored BAT's use of the term harm reduction. We searched BAT's sustainability reports from 2001/2002 (the first year of publication) to 2011 (prior to 2007 these were referred to as social reports) using the same search terms as used for the annual report searches. In October 2012 and March 2013 we accessed the Internet Archive Wayback Machine (http://www.archive.org), a historic archive of preserved webpages based on web crawler technology, which allows archived versions of websites to be visited. We entered BAT's URL (http://www.bat.com) into the Wayback Machine, selecting the earliest web page that was returned in the results (29 October 1996) and searched this page for BAT communications on harm reduction and SLT (note: the search revealed that BAT has only owned this URL from 2000, with an unrelated company owning the URL from 1996-2000). Relevant content and observations were systematically recorded. We repeated this process for all archived BAT webpages up to the last entry in 2012 (dated 23 December).

Finally, between November 2010 and January 2011 we undertook six semistructured interviews with seven key informants including three Swedish public health experts and four senior tobacco industry representatives from the European Smokeless Tobacco Council (ESTOC), BAT and Swedish Match (Europe's biggest SLT manufacturer). JTI, PMI and IMT were also invited for interview, but either declined or did not respond to our invitation. We deliberately approached Swedish public health experts because of the legal status of snus sales in Sweden. Interviews were professionally transcribed and analysed using a framework approach where emerging data were coded using a thematic structure which drew on themes identified from the existing literature while also allowing for new themes to emerge from the analysis itself. ${ }^{27}$

\section{RESULTS}

Emergence of the TTCs' discourse on harm reduction Institute of Medicine (IOM) report, 'Clearing the Smoke' and the emergence of the tobacco industry's harm reduction discourse TTCs only began using the term 'harm reduction' from 1999 onwards and consistently from $2000 .^{28-33}$ This coincided with the US Food and Drug Administration (FDA) commissioning the IOM to study the feasibility of tobacco harm reduction. ${ }^{34}$ Documentary, interview and other tobacco industry material findings suggest that this study, which took place over 1999 2001 and resulted in the 'Clearing the Smoke' report, ${ }^{35}$ was a turning point in the tobacco industry's approach to, and dialogue on harm reduction. In February 2000, the IOM invited US-based tobacco manufacturers to meet with its Working Group to discuss 'the lessons learned by the tobacco industry from previous attempts at developing products for harm reduction' ${ }^{36}$ This approach was welcomed by the tobacco industry, ${ }^{37-39}$ and it is around this time that the term 'harm reduction' gradually, but consistently, appears in the internal tobacco industry's documents. ${ }^{29}{ }^{40-48}$ Prior to 1999 no retrieved BAT or PMI documents mention the term 'harm reduction'. Instead they refer to a variety of terms including 'reduced risk', 4950 'smoking and health', 51 'risk minimization', 52 or 'reduction of noxae', 53 which appear to reflect the research focus at the time on developing a 'safer' cigarette. ${ }^{54-56}$

\section{Use of harm reduction in TTC public documentation}

Our analysis of TTCs' annual reports and BAT's social reports and website also suggests that 'harm reduction' only began to be used in TTC public documentation from 2002 onwards, its use increasing steadily thereafter albeit more by some TTCs than others (tables 1-3). BAT's first social report (2001/2002) is the first public report in which we identify any TTC mentioning 'harm reduction' (table 2). ${ }^{57}$ The fact that this report was published in 2002 limits our ability to assess whether BAT previously used this term, but the finding that its annual reports did not mention harm reduction until 2004 (table 1) make this unlikely. Similarly, analysis of BAT's website (http://www.bat. com) suggests that BAT started referring to 'less harmful' tobacco products on its website in 2005, simultaneously announcing the expansion of its product portfolio with snus (table 3).

\section{TTC approach to and perceived benefits of harm reduction} Dialogue with, and access to, scientists, public health community and policy makers

Shortly after the IOM initiated its study, BAT commissioned consultancy firm, The Lewin Group to establish a public engagement schedule to support the development of a 'Harm Reduction Strategy'. ${ }^{58}$ The Lewin Group's proposal suggested that dialogue take place with health professionals and policy makers to explore how they might find harm reduction acceptable, followed by a 'public forum' with smokers aiming to 'stimulate public debate, raise issues relating to harm reduction for committed smokers and provide a platform for further 
Table 1 References to 'harm reduction' or 'reduced harm' and 'smokeless tobacco' or 'snus' in TTCS annual reporting

\begin{tabular}{|c|c|c|c|c|c|c|c|c|}
\hline \multirow[b]{2}{*}{ Year } & \multicolumn{2}{|c|}{ BAT* } & \multicolumn{2}{|c|}{ IMT } & \multicolumn{2}{|c|}{ JTIt } & \multicolumn{2}{|l|}{ PMI } \\
\hline & HR & SLT & HR & SLT & HR & SLT & HR & SLT \\
\hline 1997 & 0 & 0 & 0 & 0 & - & - & - & - \\
\hline 1998 & - & - & 0 & 0 & - & - & - & - \\
\hline 1999 & 0 & 0 & 0 & 0 & - & - & - & - \\
\hline 2000 & 0 & 0 & 0 & 0 & - & - & - & - \\
\hline 2001 & 0 & 0 & 0 & 0 & - & - & - & - \\
\hline 2002 & 0 & 0 & 0 & 0 & - & - & 0 & 0 \\
\hline 2003 & 0 & 0 & 0 & 0 & - & - & 0 & 0 \\
\hline 2004 & 5 & 0 & 0 & 0 & - & - & 1 & 0 \\
\hline 2005 & 9 & 29 & 0 & 9 & 0 & 0 & 0 & 0 \\
\hline 2006 & 12 & 9 & 0 & 8 & 0 & 0 & 0 & 2 \\
\hline 2007 & 11 & 14 & 0 & 6 & 0 & 1 & 0 & 7 \\
\hline 2008 & 6 & 47 & 0 & 6 & 0 & 0 & 3 & 1 \\
\hline 2009 & 7 & 15 & 0 & 14 & 0 & 0 & 3 & 2 \\
\hline 2010 & 13 & 47 & 0 & 13 & 0 & 16 & 1 & 1 \\
\hline 2011 & 9 & 5 & 0 & 12 & 0 & 9 & 0 & 1 \\
\hline 2012 & - & - & 0 & 9 & 0 & 8 & - & - \\
\hline
\end{tabular}

*BAT's 1998 annual report is unavailable.

tResults are based on JTI's annual reports, which also include reporting on JTI's domestic tobacco market and its pharmaceutical and food business. Earlier copies are were not available on JTI's website, or in the British Library.

BAT, British American Tobacco; HR, 'harm reduction' or 'reduced harm'; IMT, Imperial Tobacco; JTI, Japan Tobacco International; PMI, Philip Morris International; SLT, 'smokeless tobacco' or 'snus'; TTCs, transnational tobacco companies.

public relations' (authors' emphasis). ${ }^{58}$ It is unclear whether BAT followed through on The Lewin Group's proposal, although in November 2000 BAT organised a risk assessment workshop for academics in the $\mathrm{UK}^{59-61}$ to discuss "Tobacco Harm Reduction' Assessment Criteria'. ${ }^{62}$ Six BAT scientists and nine external scientists attended, ${ }^{63-65}$ including toxicologist Jim Bridges who chaired the workshop on BAT's behalf. ${ }^{61}$ 65-67 Documents show that BAT attempted to include the UK Department of Health (DH) in this event, but that the $\mathrm{DH}$ declined. ${ }^{6068}$

Subsequently, 'The strategy of using the IOM report as a catalyst for further dialogue with UK scientific stakeholders' was discussed at an April 2001 BAT operational planning meeting. ${ }^{69}$ In an interview, the BAT representative also stressed the importance of dialogue with the public health community, stating that the tobacco industry and public health community have previously worked in silos, whereas dialogue would enable BAT to determine what, and how much, harm reduction science it should be doing, and would enable public health to better understand smokers and their needs (interview December 2010). Significantly, BAT and ESTOC interviewees attribute BAT's decision to add snus to its portfolio, and brand snus with existing cigarette brands like Lucky Strike (an issue which appears to be controversial within industry, see box 1) to dialogue with, and encouragement from, UK public health experts ${ }^{70}$ (interviews 25 November and 9 December 2010).

TTCs' use of harm reduction to signal alignment of tobacco industry interests with public health is also apparent in contemporary corporate materials. Public health experts' views on the benefits of harm reduction are cited on BAT's and PMI's websites, ${ }^{73} 74$ and when BAT first integrated a section on harm reduction on its website it stated that BAT would continue 'to seek common ground on harm reduction with health policymakers, who are looking to achieve a reduction in the net public health impact of tobacco use' (archived version http:/ www.bat.com 9 August 2007, Harm Reduction section, accessed 13 March 2013). PMI's 2008 annual report states that it supports regulations that 'are aligned with the public health objective of reducing harm caused by tobacco products' (yet noting that it won't 'support every proposal made by public health groups'). ${ }^{75}$

Similarly, TTCs' websites ${ }^{76-78}$ and BAT company reports ${ }^{57} 79-81$ underline a role for harm reduction in establishing dialogue with and access to policy makers. BAT suggests in its first Social Report published in 2002 that the tobacco industry and governments 'work together as partners, rather than adversaries'. ${ }^{57}$ In 2009 BAT's website reported that BAT had contacted the FDA (which had just been given the authority to regulate tobacco products in the USA) to share information about BAT's proposed harm reduction framework and 'aid regulators in assessing any such (potentially reduced harm) new products' (archived version http:/ www.bat.com 30 September 2009, Harm Reduction section, accessed 13 March 2013).

TTCs' use of harm reduction to gain access to policy makers was also reflected in the internal documents. For example, in July 2000 BAT arranged a meeting with $\mathrm{DH}$ officials to discuss risk communication and 'safer' cigarettes. ${ }^{82}$ Afterwards BAT noted there was an appetite among government officials to 'reach consensus' on the harm reduction issue, and that harm reduction could be used to establish ongoing access to, and dialogue with, senior government officials. ${ }^{82}$ Likewise, documents suggest that in 2000 PMI had had dialogue on reduced harm product development with IOM, Health Canada, the EU Commission, World Health Organization (WHO), among others, ${ }^{83}$ and had approached the DH to set up a meeting 'to share further information' on reduced harm products. ${ }^{84-86}$ On 12 November 2001 DH representatives visited PMI's R\&D facility in Germany, INBIFO. ${ }^{87}$ Whereas, in the 1970 s and 1980s, PMI had attempted to ensure its ownership of INBIFO was kept secret (a time when the tobacco industry was still claiming that evidence of the toxic effects of smoking was inconclusive), ${ }^{87} \mathrm{PMI}$ now welcomed government officials to this facility to discuss its harm reduction programme. ${ }^{43} 88-90$ Significantly, documents suggest this study trip was initiated by the $\mathrm{DH}^{90-92}$

That policy makers remain a key target of the TTCs' harm reduction discourse was confirmed by the BAT interviewee who noted that BAT was trying to engage with governments on harm reduction (interview December 2010). Despite BAT's efforts to engage in dialogue with DH on harm reduction in 2009 and 2010 (the latter after a new government came into power subsequently entering into 'responsibility deals' with the food and alcohol industries ${ }^{93}$ ), efforts had been unsuccessful (interview December 2010).

Responsibility and 'Improvement of credibility'

Simultaneous with the public health community's emergent interest in tobacco harm reduction, ${ }^{42}$ TTC's corporate social responsibility (CSR) agenda (initiated by PMI and BAT in $1997^{93-95}$ ) was increasing in prominence and our findings suggest they were mutually reinforcing. Existing research shows the CSR agenda emerged once evidence from US lawsuits began to seriously damage the tobacco industry's reputation, ending its insider status with governments and,${ }^{96}$ its golden era, dominated by voluntary agreements between government and an industry that 'could be relied on to act responsibly'. ${ }^{16} 97$ To regain the policy influence TTCs had previously enjoyed, BAT recognised the importance of rebuilding its reputation. ${ }^{93}$ 
Table 2 Number of references to 'harm reduction' or 'reduced harm' and 'smokeless tobacco' or 'snus' in BAT's social reports from 2001/2002 to 2011 (name changed to 'sustainability reports' from 2007 thereafter)

\begin{tabular}{rllllrrrrrrr}
\hline & $2001 / 2002$ & $2002 / 2003$ & $2003 / 2004$ & $2004 / 2005$ & 2005 & 2006 & 2007 & 2008 & 2009 & 2010 & 2011 \\
\hline HR & 2 & 2 & 3 & 54 & 72 & 16 & 41 & 41 & 100 & 247 & 232 \\
SLT & 0 & 2 & 0 & 29 & 117 & 5 & 38 & 48 & 52 & 35 & 19 \\
\hline
\end{tabular}

BAT, British American Tobacco; HR, 'harm reduction' or 'reduced harm'; SLT, smokeless tobacco.

Shortly after the IOM invited the tobacco industry to engage on harm reduction, BAT's Adrian Marshall (who had established BAT's CSR programme in $1999^{98}$ ) identified harm reduction as one of six key 'reputation management initiatives"99 that would help BAT rebuild its reputation as a responsible company. ${ }^{39}$ Shortly afterwards, BAT's scientist, Eian Massey, highlighted the reputational opportunities the IOM study created, recommending that its US subsidiary should 'address the agenda of us being a responsible Company, ${ }^{40}$ in its correspondence with IOM. Previous research shows that BAT considered harm reduction a preferred CSR initiative because it was politically salient, was unlikely to be seen as undermining other tobacco control policies, and dialogue on the issue could be represented as 'the morally right thing to do'. ${ }^{93}$

Like BAT, PMI also considered harm reduction an opportunity to rebuild corporate legitimacy. Handwritten comments on the agenda of a September 2000 PMI meeting in Hong Kong to brief staff on PMI's research strategy, noted that 'improvement of credibility' was to be the overall result of PMI's harm reduction efforts. ${ }^{42}$ Similarly, an April 2001 draft statement of CSR principles declared that PMI 'will focus our efforts on harm reduction as it applies to our product, and to or policies, programmes and positions ${ }^{100}$ and PMI staff surveys in 2002 identified harm reduction as central to corporate reputation. ${ }^{101}$

That harm reduction became important to TTCs' CSR strategies, was confirmed by the BAT interviewee who reported that BAT's early stakeholder dialogue events, initiated in 2001 as part of its emergent CSR programme, ${ }^{94}$ made BAT understand the importance of doing, and being seen to do, reduced harm research (interview December 2010). BAT's subsequent social reports ${ }^{57}$ appear to have addressed this concern; mentions of harm reduction increasing over time to become a key focus of these reports (table 2). BAT's website was also established in 2000 ostensibly as part of BAT's emerging CSR strategy given that the website's purpose was 'to explain more about what we do and what we believe in', ${ }^{102}$ including highlighting that BAT was involved in 'product modification research' to address health concerns (table 3). By drawing attention to their attempts to reduce the risk of smoking, TTCs positioned themselves as partners rather than adversaries in achieving public health gains. $^{57}$ In its 2010 Sustainability Report, BAT remarked that 'stakeholders who do talk with us often seem surprised by our candour and willingness to listen. Some are people and groups who would not have engaged with us a few years ago'. ${ }^{103}$

\section{DISCUSSION}

This study demonstrates that TTCs' adoption and subsequent use of the term harm reduction occurred in direct response to the public health agenda (which TTCs had been monitoring closely). The 'Clearing the Smoke' study by IOM appears to have been pivotal in shaping the tobacco industry discourse on harm reduction. Our findings demonstrate that harm reduction serves TTC interests in two main, mutually reinforcing, ways. First TTCs use harm reduction to facilitate access to, and

Table 3 Timeline of BAT harm reduction discourse on BAT's corporate website (http://www.bat.com), based on archived webpages (dating from 1996-2012) available from http://www.archive.org

\begin{tabular}{|c|c|}
\hline Date & Emergence and key changes to harm reduction and snus rhetoric \\
\hline 1996-2000 & - Website owned by an unrelated non-tobacco company \\
\hline May 2000 & $\begin{array}{l}\text { BAT set up website to 'help you know us (BAT) a little better, and to balance the debate on issues that can be controversial'. } \\
\text { Drop down main menu directs to BAT's views on smoking, marketing, corporate citizenship, environment, health and safety, and people. } \\
\text { Claims that smoking as a cause of certain diseases is the 'working hypothesis of much of our product modification research'. }\end{array}$ \\
\hline May 2005 & $\begin{array}{l}\text { Press release on BAT's snus investments added, saying it aims to give 'smokers the chance to enjoy a less harmful form of tobacco' } \\
\text { BAT also states it supports the lifting of the EU ban on snus sales, pointing at the 'significantly lower health risks' and arguing that marketing } \\
\text { should be aimed only 'at adults who have chosen to consume tobacco' }\end{array}$ \\
\hline Aug 2007 & $\begin{array}{l}\text { Significant website restructure, with new main section on 'health and science'. First time that 'harm reduction' and 'smokeless tobacco and } \\
\text { health' are dedicated subcategories. } \\
\text { BAT claims its investment in snus is 'in line with our [BAT's] continuing efforts in harm reduction and a response to those public health } \\
\text { stakeholders who told us they believe that snus, properly regulated, can contribute to reducing the health impact of tobacco use'. }\end{array}$ \\
\hline March 2008 & $\begin{array}{l}\text { Harm reduction is now referred to as 'a key element of our [BAT's] business strategy'. } \\
\text { BAT's new website, bat-science.com, is promoted ('written by scientists for scientists'), with a new external link to the IOM report added. }\end{array}$ \\
\hline Oct 2010 & BAT adds video 'The Science of Harm Reduction' to its website. \\
\hline April 2011 & $\begin{array}{l}\text { BAT announces its establishment of Nicoventures, a stand-alone company which will focus on nicotine-only products, calling it 'a natural } \\
\text { extension' of their 'approach to tobacco harm reduction that has been developed over years'. }\end{array}$ \\
\hline June 2011 & - BAT indicates it no longer runs snus test markets in South Africa, Canada and Japan, and only sells snus in Sweden and Norway. \\
\hline March 2012 & $\begin{array}{l}\text { The 'smokeless tobacco and health' section has been moved away from the core part of the Health and Science part, to a drop-down menu on } \\
\text { the left margin. }\end{array}$ \\
\hline Dec 2012 & $\begin{array}{l}\text { BAT announces it has acquired an e-cigarette company and claims, as with Nicoventures, it's a natural extension of their approach to harm } \\
\text { reduction. }\end{array}$ \\
\hline
\end{tabular}


Box 1 Tobacco companies' perspectives on snus branding.

The issue of cigarette branded snus appears to be debated within the tobacco industry. The Swedish Match interviewees noted that their market research indicates that full time snus consumers (including ex-smokers) do not want snus linked to cigarettes or smoking, and expressed discomfort about cigarette branded snus (interview January 2011). Similarly, the European Smokeless Tobacco Council interviewee claimed that cigarette branded snus had not succeeded in the Swedish market, and suggested that non-cigarette branded snus was better able to communicate a reduced risk message (interview November 2010). The BAT interviewee on the other hand reported that its decision to brand snus with a cigarette brand (ie, Lucky Strike and Peter Stuyvesant) had been based on advice from UK public health experts, who had argued that if BAT were to be serious about switching smokers from cigarettes to snus, they should put their biggest cigarette brand on it (interview, December 2010). Interestingly, Euromonitor 2009 sales data indicate that cigarette branded snus represented only $2 \%$ market share in Sweden, ${ }^{71}$ and $3.6 \%$ in Norway, ${ }^{72}$ with BAT's traditional snus brands (Granit and Mocca) showing slightly bigger growth than its Lucky Strike and Camel Snus.

dialogue with scientists, public health experts and policy makers, presenting themselves as 'partners, rather than adversaries ${ }^{57}$ who share a common goal. Second, TTCs considered harm reduction a 'reputation management initiative', ${ }^{99}$ facilitating the tobacco industry's image rehabilitation as a 'responsible business'. From the beginning, harm reduction was intimately linked to BAT's and PMI's emerging CSR strategies, providing a means of increasing corporate credibility with stakeholders; with social reports and corporate websites used to communicate this message.

Our findings are consistent with previous research showing that the TTCs saw HR as a means of improving their corporate reputation to regain access to regulators and, with that, influence over tobacco control policy. ${ }^{93} 96$ Both support our earlier work ${ }^{16}$ which also challenges TTCs' purported commitment to harm reduction by demonstrating that TTCs' interest and investments in SLT in Europe were defensive and originated from a desire to generate new tobacco sales 'without cannibalising existing profits from cigarettes', ${ }^{104}$ rather than a desire to reduce harm from tobacco. This paper details how TTCs intended to harness those opportunities and suggests that TTCs' harm reduction discourse should be seen as opportunistic tactical adaptation to policy change rather than a genuine commitment to harm reduction. While our analysis strongly suggests that BAT's and PMI's main interests in harm reduction were access and reputation, we cannot rule out the possibility of a genuine commitment to harm reduction. We note, however, that there was very little evidence of this relative to the evidence of reputational and access benefits.

A further finding of interest is the difference between tobacco companies in their approach to snus branding. The cigarette manufacturers have branded some of their snus with cigarette brands (according to BAT in response to public health advice), while Swedish Match, which no longer has any cigarette interests, cites market research that snus users (including ex-smokers) prefer snus brands. Both Swedish Match and ESTOC appear to contest whether the cigarette branded snus produced by cigarette manufacturers can contribute to harm reduction. To our knowledge there are no published data on this. This highlights the complexity and the lack of detailed knowledge about the potential for snus as a harm reduction product.

\section{Limitations}

This study has several limitations. The nature of tobacco industry document research means that we made decisions about which search terms and documents were most relevant. Inadvertently, this may have resulted in some relevant documents not having been included in the analysis. Furthermore, the archives comprise only those documents obtained through the discovery process in litigation. Documents may have been innocently omitted, intentionally destroyed or omitted, or inappropriately classified as privileged. To overcome these limitations we were as comprehensive as possible in our searching and reached a point of document saturation, where new searches led to documents already retrieved; an indicator that most important documents have been identified. We also used contemporary materials and interviews to triangulate our findings and overcome the issue that most retrieved documents predate 2002. The document collections do not include documents from IMT, JTI or Swedish Match; these companies may take a different approach to harm reduction than BAT and PMI (eg see box 1).

Using the Wayback Machine (archive.org) has its limitations as it is based on crawler technology which only indexes a fraction of the available content. Thus, the archived pages of BAT's website do not necessarily reflect the entire content of BAT's website at a given time. Rather, the archived website versions give a broad indication of which year BAT introduced communications on harm reduction and SLT.

\section{Policy implications}

Our analysis suggests that TTCs' harm reduction discourse should be seen as an opportunistic tactical adaptation to policy change, and shows that TTCs, in the past and present, have tried to use harm reduction discourse to access public health policy makers. Care must be taken that the harm reduction debate does not allow TTCs to re-enter the policy arena from which they have increasingly been excluded in line with Article 5.3 of WHO's Framework Convention on Tobacco Control, which aims to protect public health from the commercial and other vested interests of the tobacco industry. ${ }^{105}$

We note that various meetings discussing harm reduction, including public health conferences in the UK and FDA policy forums in the USA, ${ }^{106}{ }^{107}$ have included tobacco industry representatives. In part this is because of blurring of the definition 'tobacco industry' given TTCs' recent investments in pure nicotine and e-cigarettes. Our findings however suggest that this will merely serve to 're-normalize' an industry that is determined to be seen as a responsible business with a legitimate product, exactly as, this paper shows, industry intended. 


\section{What this paper adds}

- The 'Clearing the Smoke' study by the Institute of Medicine has been pivotal in shaping tobacco industry discourse on harm reduction. Transnational tobacco companies (TTCS) adopted the term 'harm reduction' in response to this study, and proceeded to heavily emphasise the term in corporate messaging.

- Apart from trying to make a safer cigarette, documents show that TTCs' use of harm reduction was aimed to gain access to scientists, the public health community and policy makers, and rebuild its reputation as a responsible industry.

- Although we can't rule out the possibility of a genuine commitment to harm reduction, this study suggests that TTCs' harm reduction discourse should be approached critically and seen as opportunistic tactical adaptation to policy change.

- This study underlines the importance of ensuring that the harm reduction debate does not allow TTCs to re-enter the policy area from which they have increasingly been excluded in line with Article 5.3 of WHO's Framework Convention on Tobacco Control.

Acknowledgements The authors thank all interviewees for agreeing to be interviewed. The authors would also like to thank the reviewers for their valuable feedback on the draft manuscript.

Contributors SP conducted the background work, interviews, document and secondary literature search, indexing, analysis, and drafted the manuscript. ABG directed the overall project, contributed to and supervised the interview and document analysis, wrote sections of and edited the manuscript.

Funding This research was supported by the National Cancer Institute, US National Institutes of Health (grant R01CA160695). ABG was also supported by a Health Foundation Clinician Scientist Fellowship, and ABG and SP are members of the UK Centre for Tobacco and Alcohol Studies (UKCTAS), a UK Centre for Public Health Excellence funded by the UK Clinical Research Collaboration (comprising the Economic and Social Research Council, the British Heart Foundation, Cancer Research UK, the National Institute for Health Research, and the Medical Research Council). The views expressed in this article are those of the authors and do not necessarily reflect the views of the funders.

\section{Competing interests None.}

Ethics approval This study was approved by the ethics committee of the University of Bath Department for Health in the UK. Written informed consent was obtained from all study participants prior to interviews.

Provenance and peer review Not commissioned; internally peer reviewed.

Open Access This is an Open Access article distributed in accordance with the Creative Commons Attribution Non Commercial (CC BY-NC 3.0) license, which permits others to distribute, remix, adapt, build upon this work non-commercially, and license their derivative works on different terms, provided the original work is properly cited and the use is non-commercial. See: http://creativecommons.org/ licenses/by-nc/3.0/

\section{REFERENCES}

1 Philip M. Speech by David Davies Philip Morris Senior Vice President Corporate Affairs, at the National Press Club Canberra 23 March 2005. 2005 [cited 201211 June]. http://tobacco.health.usyd.edu.au/assets/pdfs/harm-reduction/ DDaviesHR-2005.pdf

2 British American Tobacco. Research \& Development at British American Tobacco. Undated [cited 20134 March]. http://www.bat-science.com/

3 Williamson J, Proctor C. Should the health community promote smokeless tobacco (Snus): comments from British American Tobacco. PLoS Medicine 2007;4.

4 Patwardhan S. Correspondence: the potential role of snus products within a tobacco harm reduction strategy. J Pub Health Adv Access 2009;31:310-11.
5 Gartner CE, Hall WD, Chapman S, et al. Should the health community promote smokeless tobacco (Snus) as a harm reduction measure? PLoS Medicine 2007;4:1138-41.

6 Gilmore AB, Peeters $S$. Rapid response to Martin McKee's 'E-cigarettes and the marketing push that suprised everyone'. BMJ 2013;347(f5780).

7 Henningfield JE, Fagerstrom KO. Swedish match company, Swedish snus and public health: a harm reduction experiment in progress? Tobacco Control 2001;10:253-7.

8 Fagerstrom KO, Schildt E-B. Should the European union lift the ban on snus? Evidence from the Swedish experience. Addiction 2003:98:1191-5.

9 Foulds J, Ramstrom L, Burke M, et al. Effect of smokeless tobacco (snus) on smoking and public health in Sweden. Tobacco Control 2003;12:349-59.

10 Royal College of Physicians. Harm reduction in nicotine addiction: helping people who can't quit. A report by the Tobacco Advisory Goup of the Royal College of Physicians. RCP, ed. London: RCP, 2007.

11 Gartner CE, Hall WD, Vos T, et al. Assessment of Swedish snus for tobacco harm reduction: an epidemiological modelling study. Lancet (British edition) 2007;369:2010-14.

12 Parascandola M. Tobacco harm reduction and the evolution of nicotine dependence. Am J Public Health 2011;101:632-41.

13 Chapman S. Public Health Advocacy and Tobacco Control. Making Smoking History. Wiley-Blackwell, 2007.

14 European Commission. Directive 2001/37/EC of the European Parliament and of the Council of 5 June 2001 on the approximation of the laws, regulations and administrative provisions of the Member States concerning the manufacture, presentation and sale of tobacco products. Official J Eur Communities 2001 (L94):26-35.

15 Aguinaga Bialous S, Peeters $S$. A brief overview of the tobacco industry in the last 20 years. Tob Control 2012;21:92-4.

16 Peeters $\mathrm{S}$, Gilmore AB. Transnational tobacco company interests in smokeless tobacco in Europe: analysis of internal industry documents and contemporary industry materials. PLOS Medicine 2013;10.

17 Stotesbury S. Smokeless tobacco: EU dogma or dialogue? in EurActiv.com, 2012.

18 European Commission Health and Consumers Directorate-General. Report on the public consultation on the possible revision of the Tobacco Products Directive (2001/37/EC). Brussels, 2011

19 Philip Morris International. Philip Morris International's input to the public consultation on the possible revision of the Tobacco Products Directive 2001/37/ EC. 2010 [cited 201116 December 2011]. http://www.pmi.com/eng/tobacco_ regulation/submissions/documents/PMI_Input_to_public_consultation_on tobacco_products_directive_with\%20annexes_15_Dec_2010.pd

20 Burritt C. Swedish Match Targets Wall Street Smokers with Snus Tobacco, in Bloomberg online news, 2010

21 Meija AB, Ling PM. Tobacco industry consumer research on smokeless tobacco users and product development. Am J Public Health 2010;100:78-87.

22 Tomar SL, Alpert HR, Connolly GN. Patterns of dual use of cigarettes and smokeless tobacco among U.S. males: findings from national surveys. Tob Control 2010;19:104-9.

23 Tomar SL. Snuff use and smoking in U.S. men implications for harm reduction. Am J Prev Med 2002;23:143-9.

24 Hurt RD, Ebbert JO, Muggli ME, et al. Open doorway to truth: legacy of the Minnesota Tobacco Trial. Mayo Clin Proc 2009;84:446-56.

25 Forster N. The Analysis of Company Documentation. In: Cassell C, Symon G eds. Qualitative Methods in Organizational Research: A Practical Guide. Sage Publications, 1997, chapter 9.

26 Hill MR. Archival Strategies and Techniques, in Qualitative Research Methods Volume 31. Sage Publications, 1993.

27 Ritchie J, Spencer L. Qualitative Data Analysis in Applied Policy Research. In: Huberman A, Miles M eds. The Qualitative Researcher's Companion. Sage Publications Inc., 2002, 305-30.

28 Patskan G. Harm Reduction Overview, 2003. Bates no: 30341742633034174266. http://legacy.library.ucsf.edu/tid/vtu94g00

29 Patskan G. Wsa 20020000 Proposed Project Plan. Harm Reduction Guidelines, 2001. Bates no: 3012512047. http://legacy.library.ucsf.edu/tid/aus94g00

30 2000. Bates no: 2505230949/0950. http://legacy.library.ucsf.edu/tid/cgt39c00

31 Patskan G. Worldwide Scientific Affairs 20020000 Planned Project N01383. Harm Reduction Guidelines, 2002. Bates no: 3012511764-3012511765. http://legacy. library.ucsf.edu/tid/qmf91g00

32 Future Business Environment 2000. Bates no: 321519460-321519525, 2000. http://legacy.library.ucsf.edu/tid/ylk93a99

33 Future Business Environment 2001. Bates no: 324537933-324538045, 2001. http:/llegacy.library.ucsf.edu/tid/qal55a99

34 Berlind M. R582, 1999. Bates no: 2074406493A. http://legacy.library.ucsf.edu/tid/ ibr17d00 
35 Stratton K, et al. ed. Institute of Medicine, Clearing the Smoke: Assessing the Science Base for Tobacco Harm Reduction, Washington, DC: National Academy Press, 2001.

36 Stratton K. Letter from Kathleen Stratton to Rufus H Honeycutt regarding harmful substances in tobacco, 2000. Bates no: 325313912-325313915. http://legacy. library.ucsf.edu/tid/jvy92a99

37 McAdam K. Meeting with IONM, 2000. Bates no: 325193568-325193576. http://legacy.library.ucsf.edu/tid/zzr72a99

38 Stratton K. 2000. Bates no: 2505230943/0948. http://legacy.library.ucsf.edu/tid/ bgt39c00

39 Marshall A. [Transcript of Adrian Marshall]. Bates no: 325050319-325050340. http://legacy.library.ucsf.edu/tid/pap14a99

40 Massey E. Preliminary Consideration on the IOM Letter of April 17, 2000, 2000 Bates no: 325291814-325291816. http://legacy.library.ucsf.edu/tid/zgf71a99

41 Carchman RA. Harm Reduction Memo, 2000. Bates no: 2081499415/9417. http:/l legacy.library.ucsf.edu/tid/rbg47c00

42 Briefing Hong Kong, 2000. Bates no: 2082674020/4043. http://legacy.library.ucsf. edu/tid/jct55c00

43 Inbifo. Cologne Visit from Representatives of the Uk Doh 20011112 Agenda, 2001. Bates no: 2085795539. http://legacy.library.ucsf.edu/tid/cdx94c00

44 Carchman RA. Notes of the Philip Morris USA Scientific Advisory Board Meeting, 20011107 \& 20011108, 2001. Bates no: 2085523897/3899. http://legacy.library. ucsf.edu/tid/wcs10c00

45 Patskan G. Harm Reduction Overview: Review of lom Regulatory Principles and Philip Morris's Approach. Sab Meeting 20020312-20020313, 2002. Bates no: 3001346970-3001346998. http://legacy.library.ucsf.edu/tid/byg96g00

46 Carchman RA. Notes of the Philip Morris USA Scientific Advisory Board Meeting, 20020312-20020313, 2002. Bates no: 2505914404/4407. http://legacy.library. ucsf.edu/tid/kyn81c00

47 Gov't Reform Statement Summary. Doc, 2003. Bates no: 5001007419/ 5001007422. http://legacy.library.ucsf.edu/tid/wfa17a00

48 2005-04-28 Meeting with AGs from several states, Lund to NAAG (Presentation) Confidential.ppt^PowerPointPresentation.ppt, 2005. Bates no: 3116034898/ 3116034905. http://legacy.library.ucsf.edu/tid/ndb82i00

49 "Communication of information resulting from the monitoring of a reduced risk cigarette product", 1997. Bates no: 2505220705/0711. http://legacy.library.ucsf. edu/tid/nmw39c00

50 R\&D Strategic Overview, 1997. Bates no: 2076927142/7159. http://legacy.library. ucsf.edu/tid/naf85c00.

51 Research Rationale Objectives. Bates no: 102236502-102236504. http://legacy. library.ucsf.edu/tid/nkd66a99

52 BAT Group R\&D Programme 1986: Group Projects, 1985. Bates no: 107348380 107348525. http://legacy.library.ucsf.edu/tid/obs66a99

53 Reduction of "Other Noxae". Bates no: 400010843-400010848. http://legacy. library.ucsf.edu/tid/qhz42a99

54 Physicians for a Smoke-free Canada. The history of the Canadian safer cigarette program. Ottawa: Physicians for a Smoke-Free Canada, 2002.

55 Givel M. In search of the less hazardous cigarette. Int J Health Serv 2011:41:77-94

56 Proctor C. Sometimes a cigarette is just a cigarette. London: Sinclair-Stevenson, 2003.

57 British American Tobacco. Full Social Report 2001/02. 2002 [cited 20119 December]. http://www.bat.com/group/sites/uk_3mnfen.nsf/vwPagesWebLive/ D06RZGHL?opendocument\&SKN=1

58 Walker R. Proposal for the Development of a Harm Reduction Strategy (HRS), 2000. Bates no: 325295231-325295237. http://legacy.library.ucsf.edu/tid/ij|24a99

59 Risk Assessment Meeting. Bates no: 325161807-325161808. http://legacy.library. ucsf.edu/tid/onx70a99

60 McAughey J. Risk Assessment Forum-First Meeting, 2000. Bates no: 325295213-325295214. http://legacy.library.ucsf.edu/tid/gln33a99

61 Fisher A-L. Risk Assessment Meeting-30th November 2000, 2000. Bates no: 325381957-325381958. http://legacy.library.ucsf.edu/tid/bsy61a99

62 Possible Invites to Round-Table Discussion of 'Tobacco Harm Reduction' Assessment Criteria. Bates no: 325295244-325295246. http://legacy.library.ucsf. edu/tid/ojl24a99

63 Gregg EO. Risk Assessment Meeting, 2000. Bates no: 325161791-325161793. http://legacy.library.ucsf.edu/tid/jnx70a99

64 Sullivan F. Meeting on 30th November, 2000. Bates no: 325161789-325161790. http://legacy.library.ucsf.edu/tid/inx70a99

65 Scientific Research Group Meeting, 2000. Bates no: 325294841-325294847. http:/legacy.library.ucsf.edu/tid/ehl24a99

66 Fisher A-L. Risk Assessment Meeting 30th November 2000, 2000. Bates no: 325161806. http://legacy.library.ucsf.edu/tid/nnx70a99

67 Fisher A-L. Risk Assessment Meeting-30th Nov, 2000. Bates no: 325381953325381954. http://legacy.library.ucsf.edu/tid/zry61a99
68 Gregg E. Meeting on 30 November, 2000. Bates no: 325381959. http://legacy. library.ucsf.edu/tid/csy61a99

69 Operational Planning Meeting 11th April 2001-Minutes, 2001. Bates no: 325106298-325106300. http://legacy.library.ucsf.edu/tid/ebs62a99

70 British American Tobacco. Full Social Report, 2005. [cited 201318 February]. http://www.bat.com/group/sites/uk__3mnfen.nsf/vwPagesWebLive/D06RZGHL? opendocument\&SKN=1

71 Euromonitor International, Euromonitor Tobacco Passport: Sweden snus 2001 2009, by Global Brand Owner, Retail Volume, \% breakdown. 2010.

72 Euromonitor International, Euromonitor Tobacco Passport: Norway snus, 20062009, by Global Brand Owner, Retail Volume, \% breakdown. 2010.

73 British American Tobacco. Smokeless tobacco and health. 2012 [cited 201217 December]. http://www.bat.com/group/sites/uk__3mnfen.nsf/vwPagesWebLive/ D06CPCXZ?opendocument\&SKN=1

74 Philip Morris International. Health Effects of Snus. 2012 [cited 201217 December] http://www.pmi.com/eng/our_products/snus/pages/health_effects_of_snus.aspx

75 Philip Morris International, 2008 Annual Report. 2009.

76 British American Tobacco. Harm reduction: Engagement. Undated [cited 201318 March]; http://www.bat.com/group/sites/uk__3mnfen.nsf/vwPagesWebLive/ D052AMGZ?opendocument\&SKN=1

77 Japan Tobacco International. How we do business: Reduced-risk products. 2012 26 March 2012 [cited 201318 March 2013]; http://www.jti.com/how-we-dobusiness/smoking-and-health/reduced-risk-products/

78 Imperial Tobacco. Tobacco products: Potentially Reduced Exposure Products (PREPs). 2013 [cited 201318 March]; http://www.imperial-tobacco.co.uk/index. asp?page $=493$

79 British American Tobacco. Sustainability Report 2011. 2012: London.

80 British American Tobacco, Annual Review and Summary Financial Statement 2005. London, 2006:12.

81 British American Tobacco, Annual Report and Accounts 2007. London, 2008:25.

82 Payne A. Meeting with Mohammed Haroon: DOH, 2000. Bates no: 325124869325124870. http://legacy.library.ucsf.edu/tid/fkc53a99

83 2000. Bates no: 2081500255/0258. http://legacy.library.ucsf.edu/tid/klo65c00

84 Davies D. Further Meeting, 2000. Bates no: 2081500459D/0460. http://legacy. library.ucsf.edu/tid/xmo65c00

85 ZXCHERYL.SWANN@DOH.GSI.GOV.UK, RE: FURTHER MEETING, 2000. Bates no: 2081500459C. http://legacy.library.ucsf.edu/tid/wmo65c00

86 Davies D. Re: Further meeting, 2000. Bates no: 2081500459B. http://legacy. library.ucsf.edu/tid/vmo65c00

87 Diethelm PA, Rielle J-C, McKee M. The whole truth and nothing but the truth? The research that Philip Morris did not want you to see. Lancet 366:86-92.

88 Dempsey R. Re: Inbifo Follow-Up, 2001. Bates no: 2505954990. http://legacy. library.ucsf.edu/tid/sah77c00

89 Sanders E. Dawn Milner Visit, 2001. Bates no: 2085798956A. http://legacy.library. ucsf.edu/tid/ndw51h00

90 Sanders E. Re: Visit to Inbifo, 2001. Bates no: 2505940991. http://legacy.library. ucsf.edu/tid/lim43a00

91 ZXMARILYNE.DUVIGNEAU@DOH.GSI.GOV.UK, Visit to Inbifo, 2001. Bates no: 2505940992/0993. http://legacy.library.ucsf.edu/tid/kim43a00

92 Sanders E, Xx TED. Fw: Visit to Inbifo, 2001. Bates no: 2505940990. http:// legacy.library.ucsf.edu/tid/mim43a00

93 Fooks GJ, Gilmore $A B$, Smith $\mathrm{KE}$, et al. Corporate social responsibility and access to policy Élites: an analysis of tobacco industry documents. PLoS Med 2011;8 e1001076.

94 British American Tobacco. Stakeholder engagement. undated [cited 20134 February]. http://www.bat.com/groupfs/sites/BAT_8NXDKN.nsf/vwPagesWebLive/ D08QDMEK?opendocument\&SKN=1

95 Hirschhorn N. Corporate social responsibility and the tobacco industry: hope or hype? Tob Control 2004;13:447-53.

96 Fooks GJ, Gilmore A, Collin J, et al. The limits of corporate social responsibility: techniques of neutralization, stakeholder management and political CSR. J Bus Ethics 2013;112:283-99.

97 Tobacco Advertising and Sponsorship. The Next Three Years: Conference Report, 1986. Bates no: 107349911-107349918. http://legacy.library.ucsf.edu/tid/sej66a99

98 Nicoventures. Our team: Adrian Marshall. Undated [cited 201319 March]; http:// www.nicoventures.co.uk/our-team/

99 The CORA Roadmap; CORA Regional Meetings-June 2000, 2000. Bates no: 325419015-325419028. http://legacy.library.ucsf.edu/tid/xzz24a99

100 Statement of CR Principles, 2001. Bates no: 2712701389/2712701391. http:// legacy.library.ucsf.edu/tid/bgm72i00

101 PM USA corporate responsibility: internal footprint exploration-interview, 2002. Bates no: 2067193034/2067193120.001. http://legacy.library.ucsf.edu/tid/ orn29h00

102 British American Tobacco. Thank you for visiting! [Archived webpage dated 11 May 2000]. 2000 [cited 201210 October]. http://web.archive.org/web/ 
20000510214408/http://www.bat.com/bat/homepage.nsf/fsHPG_mainfs! OpenFrameSet

103 British American Tobacco. Sustainability Report 2010. 2011 [cited 201123 August 2011]. http://www.bat.com/groupfs/sites/BAT_89HK76.nsf/ vwPagesWebLive/DO7QJMQZ?opendocument\&SKN=1

104 Heath A. Smokeless Tobacco, 1984. Bates no: 301551981-301551985. http:// legacy.library.ucsf.edu/tid/qtf18a99
105 World Health Organization. WHO Framework Convention on Tobacco Control. Geneva, 2003.

106 British American Tobacco. Annual Report 2011. London, 2012.

107 Food and Drug Administration. Industry Representative Pool Risk Communication Advisory Committee. 2010. [cited 201129 March]. http://www.fda.gov/ downloads/AdvisoryCommittees/CommitteesMeetingMaterials/RiskCommunication AdvisoryCommittee/UCM199769.pdf 